\title{
Usnic acid uses mitochondrial apopitotic pathway in it's antitumoral role
}

\section{Usnik asitin tümör önleyici rolü mitokondrial apopitotik yolak üzerindedir

\author{
Zehra Dilşad Çobann ${ }^{1}$,Tuna Karaer ${ }^{2}$, Büişra Atmaca ${ }^{2}$,Halide Kaya Demirr ${ }^{1}$, Șefik Güiran ${ }^{1}$
}

'Health Sciences University, Gülhane Medical Faculty, Department of Medical Biology, Ankara, Turkey

${ }^{2}$ Gazi University, Faculty of Science, Department of Biology, Ankara, Turkey

Corresponding author: Şefik Güran, Department of Medical Biology, Gülhane Medical Faculty, Ankara, Turkey

E-mail:sefguran@yahoo.com

Received/Accepted: April 10, 2017 / June 01, 2017

Conflict of interest: There is not a conflict of interest.

\section{SUMMARY}

Objective: Usnic acid is a secondary metabolite in lichens whose role has not been completely elucidated. Lichen extracts containing usnic acid have been utilized in medicine, perfumery, cosmetics, and ecology. Usnic asit inhibits cell growth, induces the cell cycle arrest and apoptosis in human lung carcinoma.

Methods:Herein we analyzed the antitumoral effect of usnic acid on the same cell line. We analyzed the gene expression results on APOPT1, CYCS, APAF1, CASP3/9, TNF, BCL2, BCL2L1 and AIFM1 genes which have possible role on cell apopitosis.

Results: Usnic acid has stimulatory effect on APOPT1, CYCS, APAF1, CASP3, CASP9 gene expressions in our experiments.

Conclusion: Usnic acid has antitumoral effect on cancer cells, affecting on mithocondrial apopitotic genes.

Keywords : Usnic acid, cell growth, apopitosis, gene, antitumoral affect.

\section{ÖZET}

Amaç: Usnik asit likenlerde bulunan halen rolü tam olarak ortaya konamamış bir sekonder metabolittir. Usnik asit içeren liken ekstraktları tıpta, parfüm yapımında, kozmetikte ve ekolojide kullanılmaktadır. Usnik asit insan akciğer kanserinde hücre büyümesini durdurmakta, hücre döngüsünün durdurulması ve apopitozu aktive etmektedir. Çalışmamızda aynı hücre hattında usnik asitin antitümöral etkisi bakılmıştır.

Yöntem: Hücre apopitozunda rolü olan APOPT1, CYCS, APAF1, CASP3/9, TNF, BCL2 ve BCL2L1 genlerinin ekspresyon analizine bakıld1.

Bulgular: Usnik asitin APOPT1, CYCS, APAF1, CASP3, CASP9 genleri üzerinde uyarıc1 etkisi olduğu saptand1. Sonuç: Veriler usnik asitin kanser hücreleri üzerinde mitokondrial apopitotik genler aracılığı ile antitümöral etki yaptığını ortaya koymaktadir.

Anahtar sözcükler: Usnik asit, hücre büyümesi, apopitoz, gene, antitümöral etki. 


\section{INTRODUCTION}

Lichens are a world-widespread consortium of fungal and photosynthetic partners. Usnic acid is uniquely found in lichens, and is especially abundant in genera such as Alectoria, Cladonia, Usnea, Lecanora, Ramalina and Evernia. Usnic acid is one of the most common and abundant lichen metabolites, well known as an antibiotic, but also endowed with several other interesting properties ${ }^{1}$. Many lichens and extracts containing usnic acid have been utilized for medicinal, perfumery, cosmetic as well as ecological applications. Usnic acid as a pure substance has been formulated in creams, toothpaste, mouthwash, deodorants and sunscreen products, in some cases as an active principle, in others as a preservative. In addition to antimicrobial activity against human and plant pathogens, usnic acid has been shown to exhibit antiviral, antiprotozoal, antiproliferative, anti-inflammatory and analgesic activity. Ecological effects, such as antigrowth, antiherbivore and anti-insect properties, have also been demonstrated ${ }^{2}$. Usnic acid has antimicrobial, antiprotozoal, antiviral, antiproliferative, antiinflammatory, analgesic and antipyretic activity ${ }^{3}$. Anti-inflammatory, analgesic and antipyretic effects have been suggested to be linked to inhibition of prostaglandin synthesis owing to the uncoupling effects on oxidative phosphorylation ${ }^{3}$. The toxicology, the in vitro effects and the mechanism of action of usnic acid need to be investigated in greater detail in order to reach clinical trials and to allow further applications ${ }^{1}$. Usnic acid has antimitotic and antiproliferative activities against normal and malignant human cells ${ }^{4}$. Usnic acid $(50 \mathrm{mg} / \mathrm{ml})$ was shown to reduce cell counts of leukemic (K-562) and endometrial carcinoma cell lines (Ishikawa, HEC-50) when exposed to the cultures for 21 hours ${ }^{5}$. Usnic acid inhibits growth and induces cell cycle arrest and apoptosis in human lung carcinoma A549 cells ${ }^{6}$. Some studies have shown the anticancer potential of usnic acid; however, its efficacy and associated mechanisms are yet to be fully explored ${ }^{6}$.

Apoptogenic 1, Mitochondrial (APOPT1) gene is a protein that localizes to the mitochondria, where it stimulates the release of cytochrome c, thereby promoting programmed cell death ${ }^{7}$. Cytochrome $C$, Somatic (CYCS) gene encodes a small heme protein that functions as a central component of the electron transport chain in mitochondria. The encoded protein associates with the inner membrane of the mitochondrion where it accepts electrons from cytochrome $b$ and transfers them to the cytochrome oxidase complex. This protein is also involved in initiation of apoptosis ${ }^{8}$. Apoptotic Peptidase Activating Factor 1 (APAF1) gene encodes a cytoplasmic protein that initiates apoptosis ${ }^{9}$. Caspase 3 (CASP3) and Caspase 9 (CASP9) genes encode proteins which are the members of the caspase family. Sequential activation of caspases plays a central role in the execution-phase of cell apoptosis ${ }^{10}$. Singt et al. reported that usnic acid inhibits cell growth involving G0/G1 phase cell cycle arrest and induces cell death via mitochondrial membrane depolarization and induction of apoptosis in A549 cells ${ }^{6}$. Tumor Necrosis Factor (TNF) protein as a cytokine is involved in the regulation of a wide spectrum of biological processes including cell proliferation, differentiation, apoptosis, lipid metabolism, and coagulation ${ }^{11}$. BCL2, Apoptosis Regulator (BCL2) gene encodes an integral outer mitochondrial membrane proteins that block the apoptotic death ${ }^{12}$. BCL2 Like 1 (BCL2L1) gene is located at the outer mitochondrial membrane, and have been shown to regulate outer mitochondrial membrane channel (VDAC) opening ${ }^{13}$. Apoptosis Inducing Factor, Mitochondria Associated 1 (AIFM1) gene encodes a flavoprotein essential for nuclear disassembly in apoptotic cells ${ }^{14}$. So, we decided to find out the alterations of $A P O P T 1$, CYCS, APAF1, CASP3/9, TNF, BCL2, BCL2L1 and $A I F M 1$ genes.

Herein, we assessed the anticancer potency of usnic acid. We tried to find out the molecular gene alterations on the APOPT1, CYCS, APAF1, CASP3/9, TNF, BCL2, BCL2L1 and AIFM1 genes in usnic acid treatment on A549 cells. Usnic acid treatment decreased total cell number and enhanced cell death in tumor cell culture. Usnic acid treatment increased the expressions of APOPT1, CYCS, APAF1, CASP3, CASP9 genes. The proliferation of tumor cells was decreased tumor cell's growth and proliferation by using mithocondrial apopitotic genes.

\section{MATERIAL AND METHODS}

This study is supported by Gülhane Military Medical Academy, Health Sciences Institute (Gülhane Military Medical Academy AR-2013/43Ethical Board Decision GMTA-2013-22).

\section{Preparation of Extract Usnic Acid Solutions}

We supplied usnic acid from Sigma Aldrich [329967-98\% (Aldrich)]. We used Physiological Saline Solution (PSS) for dilutions in control and 
study groups. The usnic acid solutions were prepared in different concentrations $(1 \mu \mathrm{g} / \mathrm{ml}, 10$ $\mu \mathrm{g} / \mathrm{ml}, 50 \mu \mathrm{g} / \mathrm{ml}, 100 \mu \mathrm{g} / \mathrm{ml}, 200 \mu \mathrm{g} / \mathrm{ml}, 500$ $\mu \mathrm{g} / \mathrm{ml})$.

\section{Cell Culture of Human lung carcinoma A549}

A549 cells was used for finding the apopitotic mechanisms in usnic acid at gene level. A549 cells (ATCC No: CCL-185) were cultured in flasks in RPMI 1640 (Sigma-Aldrich-R8758) containing $10 \%$ fetal bovine serum (FBS) (BiochromAG, Germany), $2 \%$ penicillin and streptomycin (Biological Industries, Israel). The cells were maintained in RPMI 1640 plus 10\% FBS for at least 1 week before using them for experiments. Cells were maintained at $37{ }^{\circ} \mathrm{C}$ in a humidified atmosphere of $95 \%$ air-5\% $\mathrm{CO} 2$ in Heraeus incubator (Hanau, Germany). Cell cultures of cell line were applied due to classical standards (15). In control group, $50 \mu 1$ PSS was apllied in each culture flasks. In studying group, $50 \mu \mathrm{l}(1 \mu \mathrm{g} / \mathrm{ml}, 10 \mu \mathrm{g} / \mathrm{ml}$, $50 \mu \mathrm{g} / \mathrm{ml}$ ) usnic acid solution was added in each culture flasks. The total RNAs were in the first 24th hour by using RNA isolation kit (Roche RNA isolation kit).

\section{Cytotoxicity Assay}

Usnic acid solution in each concentration $(1 \mu \mathrm{g} / \mathrm{ml}$, $10 \mu \mathrm{g} / \mathrm{ml}, 50 \mu \mathrm{g} / \mathrm{ml}, 100 \mu \mathrm{g} / \mathrm{ml}, 200 \mu \mathrm{g} / \mathrm{ml}, 500$ $\mu \mathrm{g} / \mathrm{ml}$ ) was added as $50 \mu \mathrm{l}$ in a culture flask. Toxic dosages of all two cell culture groups were determined by using "MTT (2,3-bis(2- methoxy-4nitro-5-sulfophenyl)-5-[(phenylamino)carbonyl)]2H-tetrazolium hydroxide) assay" (16). LD50 value of usnic acid was found as $50 \mu \mathrm{g} / \mathrm{ml}$ in A549 cells. Due to MTT assay results, three different usnic acid concentrations (LD50 value of usnic acid and two lower dosages of usnic acid- $1 \mu \mathrm{g} / \mathrm{ml}$, $10 \mu \mathrm{g} / \mathrm{ml}, 50 \mu \mathrm{g} / \mathrm{ml}$ ) were chosen and studied in our experiments.

\section{Cell viability assay in cell cultures}

Trypan blue exclusion test was applied to assess cell viability with trypan blue solution. The cell viability was examined under an inverted microscope (40X magnification). The cells were identified as degenerated (blue-stained) and survived (unstained) (Sigma-Aldrich T8154 Trypan Blue solution) ${ }^{16}$. In all well plates, the surviving ratios of the cells were found over $88 \%$.

\section{RNA Isolation and C-DNA sythesis from cell cultures}

Total RNA isolation was performed from each sample seperately (in three times). Cells were harvested from flasks by tripsinization and collected in a tube. RNAs were converted to c-
DNAs by using the c-DNA synthesis kit (RevertAid cDNA Synthesis Kit, Fermentas). cDNA samples quality controlled by $\% 2$ ' lik agarose gel under ultraviolet light.

Reverse Trasnskriptaz Polimeraz Chain Reaction (RT-PCR); The gene expressions of all selected genes were studied in this panel. The studied genes were $\beta$ Actin (ACTB) (OMIM: 102630) (for control), APOPT1-Apoptogenic 1, Mitochondrial (OMIM: 616003), CYCS-Cytochrome C, Somatic (OMIM: 123970), APAF1 Gene-Apoptotic Peptidase Activating Factor 1 (OMIM: 602233), CASP3-Caspase 3 (OMIM: 600636), CASP9Caspase 9 (OMIM: 602234), TNF- Tumor Necrosis Factor (OMIM: 191160), BCL2-BCL2 Apoptosis Regulator (OMIM: 151430), BCL2L1BCL2 Like 1 (OMIM: 600039), AIFM1-Apoptosis Inducing Factor, Mitochondria Associated 1 (OMIM: 300169). All c-DNA's were used in RTPCR. All primer information used in PCR are taken from http://pga.mhg.harvard.edu/primerbank/ site. Each RT-PCR reaction was performed in $20 \mu 1$ [10 $\mu 12$ X SYBR, $5 \mu 1$ c DNA, $1 \mu 1$ primer, $3 \mu 1$ d H2O] (Roche Applied Science: LightCycler ${ }^{\circledR} 480$ System). SYBR Green PCR master mix was obtained from Applied Biosystems. RT-PCRs were applied for 6 times for each gene seperately. The gene expression levels of all genes in A549 cells in the first $24^{\text {th }}$ hour were found. The gene expression results shown on the table were found due to control group ( $\beta$ Actin) results. The results on the table were found by reducing the control results in each condition. Mean values were obtained in all groups. The critical quantification cycle $(\mathrm{Cq})$ value was defined based on the number of cycles at which the fluorescence signal can be detected above a threshold value and inversely correlated to the initial amount of DNA present in the PCR reaction 17.

Statistical Analysis; Student's t test (one sample t test) was used for two-group comparisons by using SPSS programme. The tests results ( $\mathrm{p}$ values) represent two group comparisons among the control and the usnic acid studied groups (Table 1).

\section{RESULTS}

In order to test the anti-tumour properties of usnic acid on human cells, three different concantrations were used on A549 cells. In our experiments, usnic acid in concentrations $10 \mu \mathrm{g} / \mathrm{ml}$ and $50 \mu \mathrm{g} / \mathrm{ml}$ inhibited the proliferation of tumoral cells. Usnic acid in $1 \mu \mathrm{g} / \mathrm{ml}$ concentration had no effect on tumoral cells. The results in $10 \mu \mathrm{g} / \mathrm{ml}$ and $50 \mu \mathrm{g} / \mathrm{ml}$ concentrations indicated that usnic acid strongly inhibits tumoral cell growth and proliferation in 
certain concentrations. In cell viability assay results, cell viability of usnic axcid applied in A549 cell cell culture group were find lower (88\%-10 $\mu \mathrm{g} / \mathrm{ml}$ usnic acid and 90\%-50 $\mu \mathrm{g} / \mathrm{ml}$ usnic acid) than control group (\%91).

In our study, the gene expression diferentiations were detected by Real-time PCR. The results were shown on table. Due to expression values of selected genes which participate on apopitotic pathways, no change was occurred in uses of 1 $\mu \mathrm{g} / \mathrm{ml}$ usnic acid concentration. In the analyses of $1 \mu \mathrm{g} / \mathrm{ml}$ usnic acid concentration, no statistical difference was observed due to control results $(p \geq 0,05)$, except in CASP3 gene analyses results
(Table). The APOPT1, CYCS, APAF1, CASP3 and $C A S P 9$ genes had higher gene expression results in usnic acid $10 \mu \mathrm{g} / \mathrm{ml}$ and $50 \mu \mathrm{g} / \mathrm{ml}$ concentrations than control. In TNF, BCL2, BCL2L1 and AIFM1 gene analyses, no significant difference was observed in RT-PCR analyses $(\mathrm{p} \geq 0,05)$ (Table).

So, antiproliferatif effect of usnic ascid on human lung cancer tumaral cells in our experiments was found in our analyses. Usnic acid in certain concentrations did antitumoral effect on these cell line using APOPT1,CYCS, APAF1, CASP3 and $C A S P 9$ genes which have role on tumor apopitotic pathways.

Table 1. The gene expression results of usnic acid in selected genes participate on apopitotic pathways in our experiment.

\begin{tabular}{|l|l|l|l|l|l|l|l|}
\hline Genes & Control & $\begin{array}{l}\text { Usnic acid } \\
(\mathbf{1} \boldsymbol{\mu g} / \mathbf{m l})\end{array}$ & $\mathbf{p}$ value & $\begin{array}{l}\text { Usnic acid } \\
\mathbf{( 1 0} \boldsymbol{\mu g} / \mathbf{m l})\end{array}$ & $\mathbf{p}$ value & $\begin{array}{l}\text { Usnic acid } \\
\mathbf{( 5 0} \boldsymbol{\mu g} / \mathbf{m l})\end{array}$ & $\mathbf{p}$ value \\
\hline APOPT1 & $0,096 \pm 0.03$ & $0,090 \pm 0.04$ & $\mathrm{p} \geq 0,05$ & $0,245 \pm 0.09$ & $\mathrm{p}<0,05$ & $0,986 \pm 0.22$ & $\mathrm{p}<0,05$ \\
\hline CYCS & $0,004 \pm 0.07$ & $0,006 \pm 0.12$ & $\mathrm{p} \geq 0,05$ & $0,011 \pm 0.12$ & $\mathrm{p}<0,05$ & $0,009 \pm 0.02$ & $\mathrm{p}<0,05$ \\
\hline APAF1 & $1.112 \pm 0.03$ & $1.122 \pm 0.11$ & $\mathrm{p} \geq 0,05$ & $2.132 \pm 0.16$ & $\mathrm{p}<0,05$ & $2.144 \pm 0.33$ & $\mathrm{p}<0,05$ \\
\hline CASP3 & $0.122 \pm 0.17$ & $0.142 \pm 0.10$ & $\mathrm{p}<0,05$ & $0.152 \pm 0.09$ & $\mathrm{p}<0,05$ & $0.202 \pm 0.09$ & $\mathrm{p}<0,05$ \\
\hline $\boldsymbol{C A S P 9}$ & $1.899 \pm 0.27$ & $1.802 \pm 0.24$ & $\mathrm{p} \geq 0,05$ & $2.802 \pm 0.44$ & $\mathrm{p}<0,05$ & $3.002 \pm 0.64$ & $\mathrm{p}<0,05$ \\
\hline $\boldsymbol{T N F}$ & $0.060 \pm 0.03$ & $0,060 \pm 0.01$ & $\mathrm{p} \geq 0,05$ & $0.050 \pm 0.01$ & $\mathrm{p} \geq 0,05$ & $0.055 \pm 0.02$ & $\mathrm{p} \geq 0,05$ \\
\hline BCL2 & $0,099 \pm 0.09$ & $0,101 \pm 0.10$ & $\mathrm{p} \geq 0,05$ & $0,095 \pm 0.13$ & $\mathrm{p}<0,05$ & $0,098 \pm 0.13$ & $\mathrm{p} \geq 0,05$ \\
\hline BCL2L1 & $0,637 \pm 0.19$ & $0,629 \pm 0.20$ & $\mathrm{p} \geq 0,05$ & $0,631 \pm 0.08$ & $\mathrm{p} \geq 0,05$ & $0,632 \pm 0.09$ & $\mathrm{p} \geq 0,05$ \\
\hline AIFM1 & $0,009 \pm 0.07$ & $0,008 \pm 0.03$ & $\mathrm{p} \geq 0,05$ & $0,008 \pm 0.02$ & $\mathrm{p} \geq 0,05$ & $0,009 \pm 0.02$ & $\mathrm{p} \geq 0,05$ \\
\hline
\end{tabular}

\section{DISCUSSION}

One of the ways of searching potentially new anticancer drugs is testing the various naturally synthesized compounds like lichens to be effective against various cancer in vitro models. Usnic acid as a lichen metabolite is known to exert antimitotic and antiproliferative activities against normal and malignant human cells. Usnic acid blocks cell cycle progression and induces cell death through apoptosis ${ }^{18}$. Usnic acid treatment of breast adenocarcinoma MCF-7 and human non-small cell carcinoma H1299 cells did not result in any morphological changes in microtubules or increase in the mitotic index. O'Neill et al. explained that the antineoplastic activity of usnic acid was not related to alterations in the formation and/or stabilisation of microtubules ${ }^{19}$. In comparison with parietin and gyrophoric acid, the suppression of viability and cell proliferation by usnic acid or atranorin was found to be more efficient at equitoxic doses. Usnic acid and atranorin correlated more strongly with an increased number of floating cells or a higher apoptotic index. Bačkorová et al. found the cell cycle distribution is important for the drug sensitivity ${ }^{18}$. Like observed in literature, usnic acid had antiproliferative effect on human tumor cells in our analyses. We observed the antitumoral effect on certain usnic acid dosages.

Apoptosis is another mechanism affected on usnic acid's antitumoral effect. Brisdelli et al.'s study was pointed out this effect of usnic acid. In this study, the effects of six lichen metabolites (diffractaic acid, lobaric acid, usnic acid, vicanicin, variolaric acid, protolichesterinic acid) were analyzed on proliferation, viability and reactive oxygen species level towards three human cancer cell lines [MCF-7, HeLa (cervix adenocarcinoma) and HCT-116 (colon carcinoma)]. Their study revealed that the antiproliferative activity of protolichesterinic acid in HeLa cells. It was related to its ability to induce programmed cell death involving caspases ${ }^{20}$. Apoptosis is caused by proteases, known as "caspases," which specifically target cysteine aspartyl. These caspases activate themselves and each other. Within these proteolytic cascades, caspases can be positioned as either upstream "initiators" or downstream "effectors" of apoptosis. Several pathways for activating caspases exist ${ }^{21}$. First, there are thirty members of the TNF family receptors; eight contain a so-called death domain in their cytosolic tail ${ }^{22}$. Second is the intrinsic pathway, in which 
mitochondria induces apoptosis by releasing cytochrome $\mathrm{c}$ into the cytosol. The released cytochrome $\mathrm{c}$ assembles a multiprotein caspaseactivating complex, referred to as the "apoptosome" 23. A third pathway for apoptosis induction is specific to natural killer-NK cells, which spray apoptosis-inducing protease, granzyme $\mathrm{B}$ (GraB), onto target cells ${ }^{24}$. In our analyses, APOPT1, CYCS, APAF1, CASP 3 and $C A S P 9$ genes had higher gene expression results than control. So usnic acid affect on apopitotic genes in it's antitumoral effect (Table).

APOPT1 gene encodes a protein that localizes to the mitochondria, where it stimulates the release of cytochrome $\mathrm{c}$, thereby promoting programmed cell death ${ }^{25}$. CYCS gene encodes a small heme protein that functions as a central component of the electron transport chain in mitochondria. This protein is also involved in initiation of apoptosis ${ }^{26}$. APAFl gene encodes a cytoplasmic protein that initiates apoptosis. This protein contains several copies of the WD-40 domain, a caspase recruitment domain (CARD), and an ATPase domain (NBARC). Upon binding cytochrome $\mathrm{c}$ and dATP, this protein forms an oligomeric apoptosome. The apoptosome binds and cleaves caspase 9 preproprotein, releasing its mature, activated form. Activated caspase 9 stimulates the subsequent caspase cascade that commits the cell to apoptosis 26, 27. Caspase 3 gene encodes a protein which is a member of the cysteine-aspartic acid protease (caspase) family. Sequential activation of caspases plays a central role in the execution-phase of cell apoptosis ${ }^{27}$. Caspase 9 gene encodes a member of the cysteine-aspartic acid protease (caspase) family. Sequential activation of caspases plays a central role in the execution-phase of cell apoptosis. Caspases exist as inactive proenzymes which undergo proteolytic processing at conserved aspartic residues to produce two subunits, large and small, that dimerize to form the active enzyme. This protein can undergo autoproteolytic processing and activation by the apoptosome, a protein complex of cytochrome $\mathrm{c}$ and the apoptotic peptidase activating factor 1 ; this step is thought to be one of the earliest in the caspase activation cascade ${ }^{27}$. The gene expression analysis of APOPT1, CYCS, APAF1, Caspase 3 and 9 genes were found as high in our experiments which represent the role of usnic acid in apopitosis.

TNF gene encodes a multifunctional proinflammatory cytokine that belongs to the tumor necrosis factor (TNF) superfamily. This cytokine is mainly secreted by macrophages. This cytokine is involved in the regulation of a wide spectrum of biological processes including cell proliferation, differentiation, apoptosis, lipid metabolism, and coagulation ${ }^{28}$. BCL2 encodes an integral outer mitochondrial membrane protein that blocks the apoptotic death of some cells such as lymphocytes. Constitutive expression of BCL2, such as in the case of translocation of BCL2 to Ig heavy chain locus, is thought to be the cause of follicular lymphoma ${ }^{29}$. BCL2L1 encoded by this gene belongs to the BCL-2 protein family. BCL-2 family members form hetero- or homodimers and act as anti- or pro-apoptotic regulators that are involved in a wide variety of cellular activities. The proteins encoded by this gene are located at the outer mitochondrial membrane, and have been shown to regulate outer mitochondrial membrane channel opening which is important in apoptosis of cell ${ }^{28,29}$. AIFMI gene encodes a flavoprotein essential for nuclear disassembly in apoptotic cells, and it is found in the mitochondrial intermembrane space in healthy cells. Induction of apoptosis results in the translocation of this protein to the nucleus where it affects chromosome condensation and fragmentation. In addition, this gene product induces mitochondria to release the apoptogenic proteins cytochrome $\mathrm{c}$ and caspase $9^{29}$. In our experiment, no increase was observed in the expression levels of $T N F, B C L 2, B C L 2 L 1$ and AIFM1 genes by using usnic acid. All of these results support the apopitotic role of usnic acid.

\section{REFERENCES}

1. Cocchietto M, Skert N, Nimis PL, Sava G. A review on usnic acid, an interesting natural compound. Naturwissenschaften 2002; 89: 137-46.

2. Ingólfsdóttir K. Usnic acid. Phytochemistry 2002; 61:729-36.

3. Periera EC, Nascimento SC, Lima RC, Silva $\mathrm{NH}$, Oliveira AF, Bandeira E, Boitard M, Beriel H, Vicente C, Legaz ME. Analysis of Usnea fasciata crude extracts with antineoplastic activity. Tokai J Exp Clin Med 1994; 19: 47-52.

4. O'Neill MA1, Mayer M, Murray KE, RolimSantos HM, Santos-Magalhães NS, Thompson AM, Appleyard VC. Does usnic acid affect microtubules in human cancer cells? Braz J Biol. 2010; 70: 659-64.

5. Cardarelli M, Serino G, Campanella L, Ercole P, De Cicco Nardone F, Alesiani O, Rossiello F. Antimitotic effects of usnic acid on different biological systems. Cellular and Molecular Life Sciences CMLS 1997; 53: 667-72.

6. Singh N, Nambiar D, Kale RK, Singh RP. Usnic acid inhibits growth and induces cell cycle arrest 
and apoptosis in human lung carcinoma A549 cells. Nutr Cancer 2013; 65: Suppl 1: 36-43.

7. Sun $X$, Yasuda O, Takemura Y, Kawamoto H, Higuchi M, Baba Y, Katsuya T, Fukuo K, Ogihara T, Rakugi H. Akt activation prevents Apop-1induced death of cells. Biochem Biophys Res Commun. 2008; 377: 1097-101.

8. Tafani M, Karpinich NO, Hurster KA, Pastorino JG, Schneider T, Russo MA, Farber JL. Cytochrome c release upon Fas receptor activation depends on translocation of full-length bid and the induction of the mitochondrial permeability transition. J Biol Chem 2002; 277: 10073-82.

9. Fujimoto A, Takeuchi H, Taback B, Hsueh EC, Elashoff D, Morton DL, Hoon DS. Allelic imbalance of 12q22-23 associated with APAF-1 locus correlates with poor disease outcome in cutaneous melanoma. Cancer Res. 2004; 64: 224550.

10. González D, Espino J, Bejarano I, López JJ, Rodríguez AB, Pariente JA. Caspase- 3 and -9 are activated in human myeloid HL-60 cells by calcium signal. Mol Cell Biochem 2010; 333: 1517.

11. Read RC, Teare DM, Pridmore AC, Naylor SC, Timms JM, Kaczmarski EB, Borrow R, Wilson AG. The tumor necrosis factor polymorphism TNF $(-308)$ is associated with susceptibility to meningococcal sepsis, but not with lethality. Crit Care Med 2009; 37: 1237-43.

12. Chiorazzi M, Rui L, Yang Y, Ceribelli M, Tishbi N, Maurer CW, Ranuncolo SM, Zhao H, Xu W, Chan WC, Jaffe ES, Gascoyne RD, Campo E, Rosenwald A, Ott G, Delabie J, Rimsza LM, Shaham S, Staudt LM. Related F-box proteins control cell death in Caenorhabditis elegans and human lymphoma. Proc Natl Acad Sci U S A 2013; 110: 3943-8.

13. Wang J, Beauchemin M, Bertrand R. Bcl-xL phosphorylation at Ser49 by polo kinase 3 during cell cycle progression and checkpoints. Cell Signal 2011; 23: 2030-8.

14. Rinaldi C, Grunseich C, Sevrioukova IF, Schindler A, Horkayne-Szakaly I, Lamperti C, Landouré G, Kennerson ML, Burnett BG, Bönnemann C, Biesecker LG, Ghezzi D, Zeviani $\mathrm{M}$, Fischbeck KH. Cowchock syndrome is associated with a mutation in apoptosis-inducing factor. Am J Hum Genet 2012; 91: 1095-102.

15. Gülşen MR, Uzunay NS, Fermanlı O, Çoban ZD, Öztürk D, Hamidi M, Avcu F, Güran Ş. Antiangiogenic role of Ankaferd on chick chorioallontoic membrane model. Gülhane Medical Journal 2015; 57: 274-9.

16. Kilicoglu B, Kismet K, Koru O, Tanyuksel M, Oruc MT, Sorkun K, Akkus MA. The scolicidal effects of honey. Adv Ther 2006; 23: 1077-83.

17. Tong Z, Qu S, Zhang J, Wang F, Tao J, Gao Z, Zhang Z. A modified protocol for RNA extraction from different peach tissues suitable for gene isolation and Real-Time PCR Analysis. Molecular Biotechnology 2012; 50: 229-36.

18. Bačkorová $\mathrm{M}$, Bačkor $\mathrm{M}$, Mikeš $\mathrm{J}$, Jendželovský R, Fedoročko P. Variable responses of different human cancer cells to the lichen compounds parietin, atranorin, usnic acid and gyrophoric acid. Toxicol In Vitro 2011; 25: 37-44.

19. O'Neill MA, Mayer M, Murray KE, RolimSantos HM, Santos-Magalhães NS, Thompson AM, Appleyard VC. Does usnic acid affect microtubules in human cancer cells? Braz J Biol 2010; 70: 659-64.

20. Brisdelli F, Perilli M, Sellitri D, Piovano M, Garbarino JA, Nicoletti M, Bozzi A, Amicosante G, Celenza G. Cytotoxic activity and antioxidant capacity of purified lichen metabolites: an in vitro study. Phytother Res 2013; 27: 431-7.

21. Hassan M, Watari H, Almaaty AA, Ohba Y, Sakuragi N. Apoptosis and Molecular Targeting Therapy in Cancer. Biomed Res Int 2014; 2014: 150845.

22. Locksley RM, Killeen N, Lenardo MJ. The TNF and TNF receptor superfamilies: integrating mammalian biology. Cell 2001; 104: 487-501.

23. Green DR, Kroemer G. The pathophysiology of mitochondrial cell death. Science 2004; 305(5684): 626-9.

24. Motyka B, Korbutt G, Pinkoski MJ, et al. Mannose 6-phosphate/insulin-like growth factor II receptor is a death receptor for granzyme $\mathrm{B}$ during cytotoxic T cell-induced apoptosis. Cell 2000; 103: 491-500.

25. Sun X, Yasuda O, Takemura Y, Kawamoto H, Higuchi M, Baba Y, Katsuya T, Fukuo K, Ogihara T, Rakugi H. Akt activation prevents Apop-1induced death of cells. Biochem Biophys Res Commun 2008; 377: 1097-101.

26. Morison IM, Cramer Bordé EM, Cheesman EJ, Cheong PL, Holyoake AJ, Fichelson S, Weeks RJ, Lo A, Davies SM, Wilbanks SM, Fagerlund RD, Ludgate MW, da Silva Tatley FM, Coker MS, Bockett NA, Hughes G, Pippig DA, Smith MP, Capron C, Ledgerwood EC. A mutation of human cytochrome $\mathrm{c}$ enhances the intrinsic apoptotic 
pathway but causes only thrombocytopenia. Nat Genet 2008; 40: 387-9.

27. Vakifahmetoglu-Norberg H, Ouchida AT2, Norberg E3. The role of mitochondria in metabolism and cell death. Biochem Biophys Res Commun 2017 15; 482: 426-31.
28. Apostolaki M, Armaka M, Victoratos P, Kollias G. Cellular mechanisms of TNF function in models of inflammation and autoimmunity. Curr Dir Autoimmun 2010; 11:1-26.

29. Lee HC, Wei YH. Mitochondrial role in life and death of the cell. J Biomed Sci 2000; 7: 2-15. 